\title{
Review of epidemiological studies on air pollution and health effects in children
}

\author{
Jong-Tae Lee, PhD
}

Division of Health Policy and Management, College of Health Science, Korea University, Seoul, Korea

There is a growing body of literature on the adverse health effects of ambient air pollution. Children are more adversely affected by air pollution due to their biological susceptibility and exposure patterns. This review summarized the accumulated epidemiologic evidence with emphasis on studies conducted in Korea and heterogeneity in the literature. Based on systematic reviews and meta-analyses, there is consistent evidence on the association between exposure to ambient air pollution and children's health, especially respiratory health and adverse birth outcomes, and growing evidence on neurodevelopmental outcomes. Despite these existing studies, the mechanism of the adverse health effects of air pollution and the critical window of susceptibility remain unclear. There is also a need to identify causes of heterogeneity between studies in terms of measurement of exposure/outcome, study design, and the differential characteristics of air pollutants and population.

Key words: Air pollution, Children, Respiratory health, Birth outcomes, Infant mortality, Neurodevelopment

\section{Key message}

This review summarized the accumulated epidemiologic evidence with emphasis on studies conducted in Korea and heterogeneity in the literature. Based on systematic reviews and meta-analyses, there is consistent evidence on the association between exposure to ambient air pollution and children's health, especially respiratory health and adverse birth outcomes, and growing evidence on neurodevelopmental outcomes.

\section{Introduction}

There is a growing body of literature on the adverse health effects of ambient air pollution. ${ }^{1-3)}$ Epidemiological studies to date have consistently reported that chronic and acute exposure to ambient air pollutants is related to an increased risk of cardiopulmonary health. Some of these studies focused on a susceptible population at higher risk posed by air pollution, which raised concerns regarding child susceptibility. Children are more adversely affected by air pollution due to their immature immune systems, their underdeveloped lung and metabolic systems, and the co-occurrence of infection with respiratory pathogens. ${ }^{4,5)}$ Children are also susceptible to air pollution because they spend more time outdoors and are more physically active, which results in exposure to a higher concentration of air pollution and increased ventilation rates. ${ }^{\text {) }}$

Numerous systematic reviews and meta-analyses have examined air pollution and children's health, including the World Health Organization (WHO) reports published in 2005 and 2018.5) This review is in line with previous studies that summarized and evaluated the accumulated epidemiologic evidence but puts more emphasis on studies conducted in South Korea and discusses the causes of heterogeneity in the literature. In this context, we limited the scope of this review to ambient air pollution and the most commonly investigated health outcomes.

\section{Respiratory health}

Since air pollution enters the human body through breathing, the respiratory system is primarily and directly exposed to air pollution. Numerous epidemiologic studies have investigated the respiratory effects of air pollution on children, including lung function and respiratory symptoms/diseases. The systematic reviews and meta-analyses on ambient air pollution and children's respiratory health examined here are shown in Table 1..$^{8-21)}$

Meta-analyses concluded that air pollution may adversely impact lung function. However, Ward and Ayres ${ }^{8}$ suggested that the reliability of summary effect estimates is limited due to considerable heterogeneity and possible publication bias. They highlighted the need for further research on the causes of this heterogeneity, including an analytic approach, study population, and interactions between air pollutants. Studies on the Korean population have consistently suggested adverse effects of airborne particles on lung function; ${ }^{22-24)}$ however, making a direct comparison of the effect estimates between these studies was

\footnotetext{
Corresponding author: Jong-Tae Lee, PhD. School of Health Policy and Management, College of Health Science, Korea University, 145 Anam-ro, Seongbuk-gu, Seoul 02841, Korea 
Table 1. Summary of existing meta-analyses of correlation between air pollution and children's respiratory health

\begin{tabular}{|c|c|c|c|c|c|}
\hline Study & Pollutant & Exposure period & Outcome & No. of articles ${ }^{\mathrm{a})}$ & Main result \\
\hline $\begin{array}{l}\text { Barone-Adesi et al., } \\
2015^{16)}\end{array}$ & $\mathrm{NO}_{2}$ & Long-term & Lung function (FEV 1 ) & 13 & $\begin{array}{l}\text { Increase in } \mathrm{NO}_{2} \text { was associated with lower } \mathrm{FEV}_{1} \text { (absolute } \\
\text { difference }-8 \mathrm{~mL} ; 95 \% \mathrm{Cl},-14 \text { to }-1 \mathrm{~mL} \text { per } 10 \mu \mathrm{g} / \mathrm{m}^{3}\end{array}$ \\
\hline Ward \& Ayres, 2004 ${ }^{8)}$ & $\mathrm{PM}_{10}, \mathrm{PM}_{2.5}$ & Short-term & $\begin{array}{l}\text { Lung function and respi- } \\
\text { ratory symptoms (PEF, } \\
\text { cough, LRS or wheeze) }\end{array}$ & 22 & $\begin{array}{l}\text { Increase in } \mathrm{PM}_{10} \text { and } \mathrm{PM}_{2.5} \text { were associated with lower PEF and } \\
\text { increasing risk of symptoms. Effects of } \mathrm{PM}_{10} \text { were widely } \\
\text { spread and smaller than those for } \mathrm{PM}_{2.5} \text { (change in PEF } \\
\mathrm{PM}_{2.5}:-0.063 \mathrm{~L} / \mathrm{min}, 95 \% \mathrm{Cl},-0.091 \text { to } 0.034 \mathrm{~L} / \mathrm{min} \text {; } \mathrm{PM} 10 \text { : } \\
-0.012 \mathrm{~L} / \mathrm{min}, 95 \% \mathrm{Cl},-0.017 \text { to } 0.008 \mathrm{~L} / \mathrm{min} \text { per } 1 \mu \mathrm{g} / \mathrm{m}^{3} \text { ) }\end{array}$ \\
\hline $\begin{array}{l}\text { Weinmayr et al., } \\
2010^{17)}\end{array}$ & $\mathrm{PM}_{10}, \mathrm{NO}_{2}$ & Short-term & $\begin{array}{l}\text { Lung function and respi- } \\
\text { ratory symptoms (PEF, } \\
\text { cough, LRS or wheeze) }\end{array}$ & 36 & $\begin{array}{l}\text { Increase in PM10 was associated with increasing risk of asthma } \\
\text { symptoms (OR } 1.028 ; 95 \% \mathrm{Cl}, 1.006 \text { to } 1.051 \text { per } 10 \mu \mathrm{g} / \mathrm{m}^{3} \text { ). } \\
\text { The associations of PM10 with cough and PEF were not } \\
\text { statistically significant. The results for } \mathrm{NO}_{2} \text { depended on the } \\
\text { lag times examined. }\end{array}$ \\
\hline Bowatte et al., 2015 & $\begin{array}{l}\text { TRAP: } \mathrm{NO}_{2}, \mathrm{PM}_{2.5} \text {, } \\
\mathrm{BC}\end{array}$ & Long-term & Asthma (incidence) & 19 & $\begin{array}{l}\text { Increase in } \mathrm{PM} 2.5 \text { and } \mathrm{BC} \text { were associated with increasing risk } \\
\text { of asthma (PM2.5: OR, } 1.14,95 \% \mathrm{Cl}, 1.00 \text { to } 1.30 \text { per } 2 \mu \mathrm{g} / \\
\left.\mathrm{m}^{3} ; \mathrm{BC}: \mathrm{OR}, 1.20,95 \% \mathrm{Cl}, 1.05 \text { to } 1.38 \text { per } 1 \times 10^{-5} \mathrm{~m}^{-1}\right)\end{array}$ \\
\hline Gasana et al., 2012 ${ }^{19)}$ & $\begin{array}{l}\text { Motor vehicle air } \\
\text { pollution: } \mathrm{NO}_{2} \mathrm{NO}_{2} \\
\mathrm{NOx}, \mathrm{CO}_{2} \mathrm{PM}_{2.5} \\
\mathrm{PM}_{10}, \mathrm{SO}_{2}, \mathrm{O}_{3}\end{array}$ & Long-term & $\begin{array}{l}\text { Asthma, wheeze (inci- } \\
\text { dence, prevalence) }\end{array}$ & 19 & $\begin{array}{l}\text { Increase in } \mathrm{NO}_{2}, \mathrm{NO}, \mathrm{CO}, \mathrm{PM} \text {, and } \mathrm{SO}_{2} \text { were associated with } \\
\text { increasing risk of asthma and/or wheeze (asthma prevalence } \\
\mathrm{NO}_{2} \text { : } \mathrm{OR}, 1.05,95 \% \mathrm{Cl}, 1.00 \text { to } 1.11 \text {; } \mathrm{NO}: \mathrm{OR}, 1.02,95 \% \mathrm{Cl} \text {, } \\
1.00 \text { to } 1.04 ; \mathrm{CO}: \mathrm{OR}, 1.06,95 \% \mathrm{Cl}, 1.01 \text { to } 1.12 ; \text { wheeze pre- } \\
\text { valence } \mathrm{SO}_{2}: \mathrm{OR}, 1.04,95 \% \mathrm{Cl}, 1.01 \text { to } 1.07 \text {; asthma incidence } \\
\mathrm{NO} \text { : } \mathrm{OR}, 1.14,95 \% \mathrm{Cl}, 1.06 \text { to } 1.24 ; \text { wheeze incidence } \mathrm{PM} \text { : } \\
\text { OR, } 1.05,95 \% \mathrm{Cl}, 1.04 \text { to } 1.07 \text { per } 10 \mu \mathrm{g} / \mathrm{m}^{3} \text { ) }\end{array}$ \\
\hline Khreis et al., 2017º) & $\begin{array}{l}\text { TRAP: } \mathrm{BC}, \mathrm{NO}_{2}, \mathrm{NOx} \\
\mathrm{PM}_{2.5}, \mathrm{PM}_{10}\end{array}$ & Long-term & $\begin{array}{l}\text { Asthma (incidence, life- } \\
\text { time prevalence) }\end{array}$ & 21 & $\begin{array}{l}\text { With the exception of } \mathrm{NOx} \text {, increase in all pollutants were } \\
\text { associated with increasing risk of asthma (BC: OR, } 1.08,95 \% \\
\text { Cl, } 1.03 \text { to } 1.14 \text { per } 0.5 \times 10^{-5} \mathrm{~m}^{-1} \text {; } \mathrm{NO}_{2} \text { : OR, } 1.05,95 \% \mathrm{Cl}, 1.02 \\
\text { to } 1.07 \text { per } 4 \mu \mathrm{g} / \mathrm{m}^{3} \text {; } \mathrm{NOx}: \mathrm{OR}, 1.48,95 \% \mathrm{Cl}, 0.89 \text { to } 2.45 \mathrm{per} \\
30 \mu \mathrm{g} / \mathrm{m}^{3} \text {; } \mathrm{PM} 2.5: \mathrm{OR}, 1.03,95 \% \mathrm{C}, 11.01 \text { to } 1.05 \text { per } 1 \mu \mathrm{gg} / \mathrm{m}^{3} \text {; } \\
\text { PM10: OR, } 1.05,95 \% \mathrm{Cl}, 1.02 \text { to } 1.08 \text { per } 2 \mu \mathrm{g} / \mathrm{m}^{3} \text { ) }\end{array}$ \\
\hline $\begin{array}{l}\text { Anderson et al., } \\
2013^{9)}\end{array}$ & $\mathrm{PM}_{10}, \mathrm{NO}_{2}$ & Long-term & $\begin{array}{l}\text { Asthma, wheeze (inci- } \\
\text { dence, lifetime preval- } \\
\text { ence) }\end{array}$ & 10 & $\begin{array}{l}\text { Increase in } \mathrm{NO}_{2} \text { was associated with increasing risk of asthma } \\
\text { or wheeze }\left(\mathrm{OR}, 1.05 ; 95 \% \mathrm{Cl}, 1.01 \text { to } 1.10 \text { per } 10 \mu \mathrm{g} / \mathrm{m}^{3}\right) \text {. The } \\
\text { effect of } \mathrm{PM} 10 \text { was not statistically significant. }\end{array}$ \\
\hline $\begin{array}{l}\text { Anderson et al., } \\
2013^{10)}\end{array}$ & $\mathrm{PM}_{10}, \mathrm{NO}_{2}, \mathrm{O}_{3}, \mathrm{SO}_{2}$ & Long-term & $\begin{array}{l}\text { Asthma, wheeze (pre- } \\
\text { valence) }\end{array}$ & 8 & $\begin{array}{l}\text { All pollutants were not associated with prevalence or asthma } \\
\text { or wheeze }\end{array}$ \\
\hline Lim et al., 2016 & $\mathrm{PM}_{2.5}$ & Short-term & $\begin{array}{l}\text { Hospital admissions and } \\
\text { emergency department } \\
\text { visits for asthma }\end{array}$ & 26 & $\begin{array}{l}\text { Increase in } \mathrm{PM}_{2.5} \text { was associated with hospital admissions and } \\
\text { emergency department visits for asthma (RR, } 1.048 ; 95 \% \mathrm{Cl} \text {, } \\
1.028 \text { to } 1.067 \text { per } 10 \mu \mathrm{g} / \mathrm{m}^{3} \text { ) }\end{array}$ \\
\hline Fan et al., 2016 ${ }^{11)}$ & $\mathrm{PM}_{2.5}$ & Short-term & $\begin{array}{l}\text { Emergency department } \\
\text { visits for pneumonia }\end{array}$ & 16 & $\begin{array}{l}\text { Increase in } \mathrm{PM}_{2.5} \text { was associated with emergency department } \\
\text { visits for asthma (RR, } 1.036 ; 95 \% \mathrm{Cl}, 1.018 \text { to } 1.053 \text { per } 10 \mu \\
\mathrm{g} / \mathrm{m}^{3} \text { ) }\end{array}$ \\
\hline Orellano et al., 2017 & $\begin{array}{l}\mathrm{NO}_{2}, \mathrm{SO}_{2}, \mathrm{PM}_{10} \\
\mathrm{PM}_{2.5}, \mathrm{CO}, \mathrm{O}_{3}\end{array}$ & Short-term & $\begin{array}{l}\text { Hospital admissions and } \\
\text { emergency department } \\
\text { visits for asthma }\end{array}$ & 16 & $\begin{array}{l}\text { Increase in } \mathrm{NO}_{2}, \mathrm{SO}_{2} \text { and } \mathrm{PM}_{2.5} \text { were associated with asthma } \\
\text { exacerbations }\left(\mathrm{NO}_{2} \text { : } \mathrm{OR}, 1.040,95 \% \mathrm{Cl}, 1.001 \text { to } 1.081 \mathrm{per}\right. \\
10 \mathrm{ppb} \text {; } \mathrm{SO}_{2} \text { : OR, } 1.047,95 \% \mathrm{Cl}, 1.009 \text { to } 1.086 \text { per } 10 \mathrm{ppb} \text {; } \\
\text { PM2.5: OR, } 1.022,95 \% \mathrm{Cl}, 1.000 \text { to } 1.04510 \mu \mathrm{g} / \mathrm{m}^{3} \text { ) }\end{array}$ \\
\hline Zhang et al., 2016 ${ }^{14)}$ & $\begin{array}{l}\mathrm{SO}_{2}, \mathrm{NO}_{2}, \mathrm{CO}_{1} \mathrm{O}_{3} \\
\mathrm{PM} 10\end{array}$ & Short-term & $\begin{array}{l}\text { Hospital utilization for as- } \\
\text { thma }\end{array}$ & 26 & 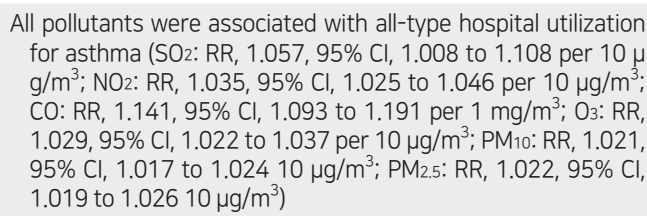 \\
\hline Mehta et al., 2013 ${ }^{15)}$ & $\mathrm{PM} 2.5$ & Long-term & $\begin{array}{l}\text { Acute lower respiratory } \\
\text { infections (ALRI) }\end{array}$ & 4 & $\begin{array}{l}\text { Increase in } \mathrm{PM}_{2.5} \text { was associated with increasing risk of ALRI } \\
\left(\mathrm{RR}, 1.12 ; 95 \% \mathrm{Cl}, 1.03 \text { to } 1.30 \text { per } 10 \mu \mathrm{g} / \mathrm{m}^{3}\right)\end{array}$ \\
\hline Nhung et al., 2017 21 ) & $\begin{array}{l}\mathrm{PM}_{10}, \mathrm{PM}_{2.5}, \mathrm{SO}_{2}, \mathrm{O}_{3} \\
\mathrm{NO}_{2}, \mathrm{CO}\end{array}$ & Short-term & $\begin{array}{l}\text { Hospital admissions and } \\
\text { emergency department } \\
\text { visits for pneumonia }\end{array}$ & 17 & $\begin{array}{l}\text { With the exception of } \mathrm{CO} \text {, all pollutants were associate with } \\
\text { pneumonia hospitalization (PM10: } \mathrm{ER}, 1.5 \%, 95 \% \mathrm{Cl}, 0.6 \% \text { to } \\
2.4 \% \text { per } 10 \mu \mathrm{g} / \mathrm{m}^{3} \text {; } \mathrm{PM} 10 \text { : } \mathrm{ER}, 1.8 \%, 95 \% \mathrm{Cl}, 0.5 \% \text { to } 3.1 \% \\
\text { per } 10 \mu \mathrm{g} / \mathrm{m}^{3} ; \mathrm{SO}_{2}: \mathrm{ER}, 2.9 \%, 95 \% \mathrm{Cl}, 0.4 \% \text { to } 5.3 \% \text { per } 10 \\
\text { ppb; } \mathrm{O}_{3}: \mathrm{ER}, 1.7 \%, 95 \% \mathrm{Cl}, 0.5 \% \text { to } 2.8 \% \text { per } 10 \mathrm{ppb} \text {; } \mathrm{NO} \text { : } \\
\text { ER, } 1.4 \%, 95 \% \mathrm{Cl}, 0.4 \% \text { to } 2.4 \% \text { per } 10 \mathrm{ppb} \text {; CO: } \mathrm{ER}, 0.9 \% \text {, } \\
95 \% \mathrm{Cl}, 0 \% \text { to } 1.9 \% \text { per } 1,000 \mathrm{ppb} \text { ) }\end{array}$ \\
\hline
\end{tabular}

FEV 1 , forced expiratory volume in one second; $\mathrm{Cl}$, confidence interval; LRS, lower respiratory symptoms; PEF, peak expiratory flow; OR, odds ratio; TRAP, traffic-related air pollution; RR, relative risk; ER, excessive risk.

a) No. of articles included in the meta-analyses (note that the number of articles can vary by air pollutants and outcomes).

difficult since they used different study designs.

As concluded by the WHO report, ${ }^{5)}$ the results of metaanalyses on asthma incidence and prevalence were inconsistent in terms of outcomes and individual pollutants. Anderson and colleagues conducted two meta-analyses on asthma incidence and prevalence and found that only $\mathrm{NO}_{2}$ was associated with the incidence of asthma., ${ }^{910)}$ In Korea, a prospective study of elementary school children showed that ambient $\mathrm{O}_{3}$ was positively associated with the 1-year prevalence of wheezing (odds ratio [OR], 1.372; 95\% confidence interval [CI], 1.016- 
1.852; per 5 ppb). ${ }^{25)}$ However, Yi et al. ${ }^{26)}$ did not find a significant association between traffic-related air pollution (TRAP) exposure and asthma prevalence in Seoul, Korea.

Emergency departments and hospital admissions for asthma have been used in many studies as a surrogate for asthma exacerbation. Several meta-analyses have consistently reported significant effects of air pollution on the increase in hospital utilization for asthma. ${ }^{11-14)}$ Fan et al. ${ }^{11)}$ and Zhang et al. ${ }^{14}$ showed that the magnitude of the association between hospital utilization for asthma and exposure to air pollution was larger in children than in adults. Previous studies conducted in Korea also provided convincing evidence of the positive association of air pollutants with hospital admissions for asthma. ${ }^{27-32)}$

Studies on asthma incidence and prevalence varied in terms of exposure assessment methods, and outcome measurements were often made via questionnaire. The studies had different designs: cohort, case-control, and cross-sectional. On the other hand, every study on asthma exacerbation used hospital records to define health outcomes. They also used time-series analyses or case-crossover designs in common to evaluate the short-term effect. These differences may be the reason why evidence of the link between air pollution and asthma exacerbation is robust, while studies on asthma incidence and prevalence reported relatively large degrees of heterogeneity and inconsistent results.

One of the diseases mainly studied in relation to respiratory health is respiratory infections, including pneumonia. In a meta-analysis, Mehta et al. ${ }^{15)}$ showed that long-term ambient particulate matter $\left(\mathrm{PM}_{2.5}\right)$ exposure was associated with an increased risk of acute lower respiratory infections. Short-term exposure to air pollution has also been reported to be associated with increased hospital admission or health care utilization for respiratory infections. ${ }^{33,34)}$

These respiratory health effects of air pollution can lead to school absenteeism for children. A study from Mexico City revealed that a high concentration of ambient ozone for 2 consecutive days increased the risk of school absenteeism for respiratory illness by about 20\%.35) Park et al. ${ }^{36)}$ showed that $\mathrm{PM}_{10}, \mathrm{O}_{3}$, and $\mathrm{SO}_{2}$ were associated with illness-related absenteeism in elementary school students in South Korea. However, the study of a cohort in southern California communities did not find a statistically significant association between school absenteeism and $\mathrm{PM}_{10}$ or $\mathrm{NO}_{2}{ }^{37)}$ Although studies on school absenteeism are limited in terms of outcome measure, these kinds of studies support the evidence that air pollution affects the respiratory health of children.

Several recent studies suggested seasonal variations in the association between air pollution and respiratory health in children. Stronger effects of air pollution were found during the cold season ${ }^{34,38)}$ or transient season. ${ }^{39)}$ These various effects of season might have been induced by a different meteorological condition affecting the distribution of air pollution or different outdoor behaviors of children affecting exposure pattern. Children's respiratory health can also be affected by seasonal factors such as viral infections or allergens. Therefore, studies of air pollution and respiratory health for children must consider season as an important factor.

\section{Adverse birth outcomes and early childhood mortality}

Adverse birth outcomes are a matter of great concern because their effects influence health throughout life. ${ }^{40-42)}$ There is growing evidence of the associations between maternal exposure to ambient air pollution and adverse birth outcomes, including low birth weight (LBW), preterm birth (PTB), stillbirth (SB), and small for gestational age (SGA). The systematic reviews and meta-analyses considered here are shown in Table $2 .{ }^{43-50)}$ Overall, there is compelling evidence that exposure to ambient air pollution, mainly $\mathrm{PM}, \mathrm{NO}_{2}, \mathrm{SO}_{2}$, and $\mathrm{CO}$, is associated with LBW, SGA, and PTB, but there is mixed evidence regarding its contributions to SB. Studies conducted in Korea also provided a consistent conclusion regarding the association between air pollution and $\mathrm{LBW},{ }^{51-53)} \mathrm{PTB},{ }^{54,55)}$ and $\mathrm{SB}^{56}{ }^{56}$

Recent studies have focused on the heterogeneity of the effects of air pollutants on adverse birth outcomes. Several studies investigated the effects of PM according to its chemical constituents to identify major contributors with detrimental health effects. ${ }^{57-59)}$ For example, a recent meta-analysis by Sun et al. ${ }^{60)}$ reported that zinc, nickel, titanium, vanadium, organic carbon, nitrate, and elemental carbon were associated with LBW. Other studies focused on population characteristics as causes of heterogeneity, such as a child's sex ${ }^{61)}$ and maternal socioeconomic status. ${ }^{62)}$ Recent studies also considered area-level characteristics such as residential socioeconomic status ${ }^{63,64)}$ or greenness level. ${ }^{65)}$ For example, Yi et al ${ }^{66}$ reported that the effect of $\mathrm{PM}_{10}$ on PTB was stronger among mothers living in deprived areas after the adjustment for individual-level socioeconomic status in Seoul, Korea.

The results of previous studies regarding the critical exposure period vary according to the study population, location, and air pollutants. A recent meta-analysis showed that the association was the strongest for $\mathrm{PM}_{2.5}$ exposure in late pregnancy with LBW infants. ${ }^{60)}$ Another meta-analysis reported the highest pooled estimates for $\mathrm{PM}_{10}$ exposure in the first trimester with LBW or PTB but no notable differences for $\mathrm{NO}_{2}$ across pregnancy trimesters. ${ }^{43)}$ Studies in Korea reported the strongest associations between exposure to air pollutants in early to midpregnancy and $\mathrm{LBW},{ }^{51,52)}$ while others reported the strongest associations between exposure to air pollution in the third trimester and PTB. ${ }^{54,67)}$ Several plausible mechanisms support early or late pregnancy as a critical period, ${ }^{60,68-70)}$ but more evidence is needed to clarify the critical window of susceptibility and its biological mechanisms.

There is also strong evidence that exposure to ambient air pollution is associated with infant mortality, particularly respiratory deaths and sudden infant death syndrome (SIDS). ${ }^{71-73)}$ In Korea, Ha et al. ${ }^{74)}$ and Hwang et $\mathrm{al}^{75)}$ reported on the effects 


\begin{tabular}{|c|c|c|c|c|}
\hline Study & Pollutant & Exposure period & Outcome & No. of article \\
\hline \multirow[t]{3}{*}{ Guo et al., 201943) } & $\begin{array}{l}\mathrm{PM}_{10}, \mathrm{PM}_{2.5}, \mathrm{NOx} \\
\mathrm{NO}_{2}, \mathrm{SO}_{2}, \mathrm{O}_{3}, \mathrm{CO}\end{array}$ & Entire pregnancy & Low birth weight & 20 \\
\hline & & & Preterm birth & 24 \\
\hline & & & $\begin{array}{l}\text { Small for gesta- } \\
\text { tional age }\end{array}$ & 8 \\
\hline \multirow[t]{2}{*}{ Li et al., 20174) } & $\mathrm{PM} 2.5$ & Entire pregnancy & $\begin{array}{l}\text { Term low birth } \\
\text { weight }\end{array}$ & 15 \\
\hline & & & Preterm birth & 14 \\
\hline $\begin{array}{l}\text { Siddika et al., } \\
2016^{45)}\end{array}$ & $\begin{array}{l}\mathrm{PM}_{10}, \mathrm{PM}_{2.5}, \mathrm{NO}_{2} \\
\mathrm{SO}_{2}\end{array}$ & Entire pregnancy & Still birth & 13 \\
\hline
\end{tabular}

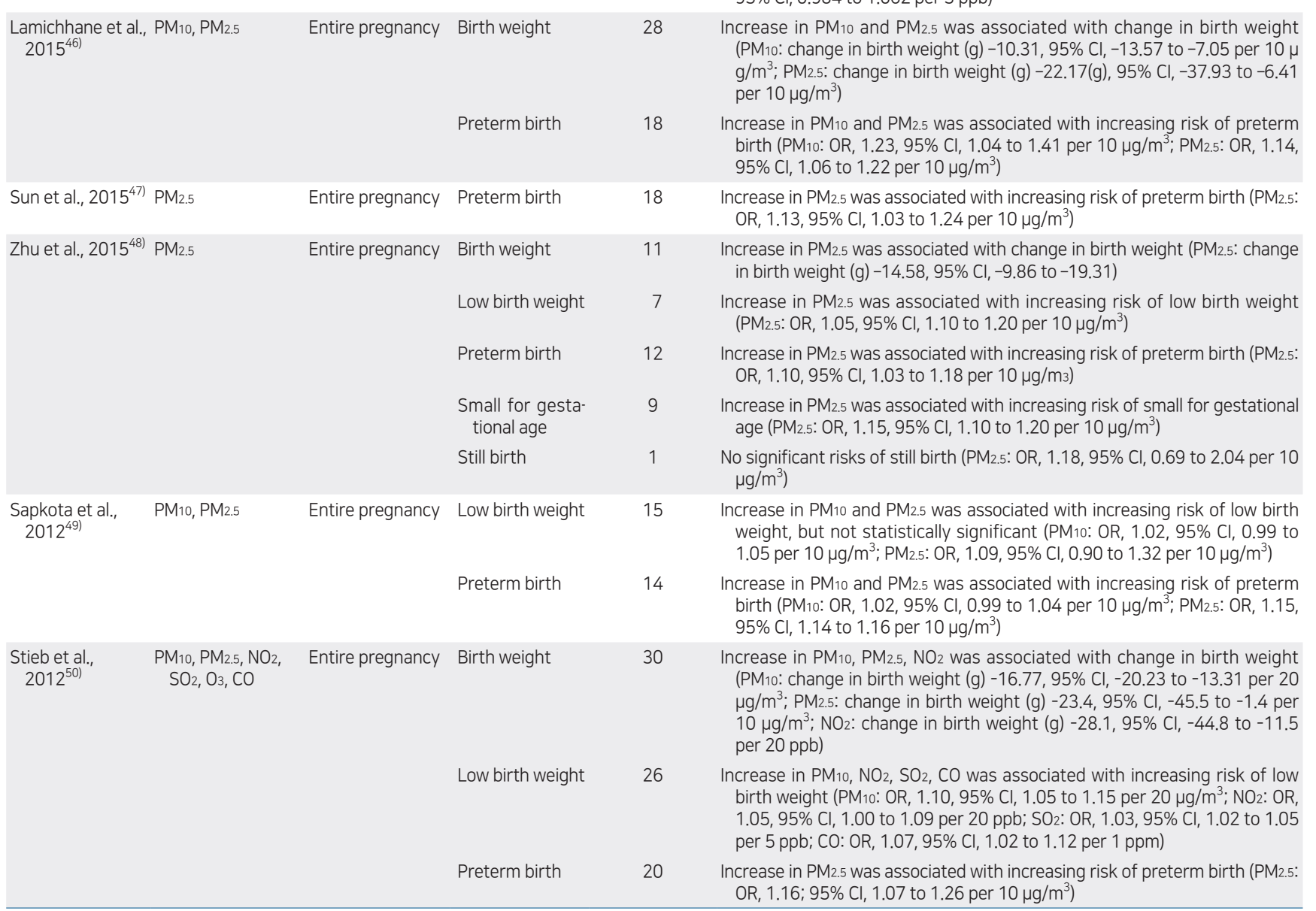

$\mathrm{OR}$, odds ratio; $\mathrm{Cl}$, confidence interval; IQR, interquartile range.

a) No. of articles included in the meta-analyses (note that the number of articles can vary by air pollutants and outcomes).

of acute exposure to $\mathrm{PM}_{10}$ on cause-specific mortality and SIDS, respectively. Most studies to date focused on short-term exposure to air pollution, and few have provided evidence of the effects of long-term exposure. For example, Son et al. ${ }^{76}$ reported the association between long-term exposure to PM (total suspended particles, $\mathrm{PM}_{10}, \mathrm{PM}_{10-2.5}, \mathrm{PM}_{2.5}$ ) and infant mortality in Seoul, Korea.

\section{Neurodevelopmental outcomes}

Neurodevelopment is an emerging research area in air pollution and children's health. Although evidence is still mounting, existing studies have suggested the potential associations between prenatal/postnatal exposure to ambient air pollution and neurodevelopmental effects such as cognitive development, 
Table 3. Summary of existing studies of correlation between air pollution and neurodevelopmental outcomes

\begin{tabular}{|c|c|c|c|c|c|}
\hline Study & Pollutant & Exposure period & Outcome & No. of articles $^{a)}$ & Main result \\
\hline $\begin{array}{l}\text { Lovasi et al., } \\
2014^{77)}\end{array}$ & PAH & $\begin{array}{l}\text { Prenatal (3rd trime- } \\
\text { ster of pregnancy) }\end{array}$ & Cognitive test score & - & $\begin{array}{l}\text { Prenatal PAH exposure above the median }\left(2.26 \mathrm{ng} / \mathrm{m}^{3}\right) \text { predicted } 3.5 \text { points } \\
\text { lower total WPPSI-R scores and } 3.9 \text { points lower verbal scores }\end{array}$ \\
\hline $\begin{array}{l}\text { Edwards et al., } \\
\qquad 2010^{78)}\end{array}$ & $\mathrm{PAH}$ & $\begin{array}{l}\text { Prenatal ( } 2 \text { nd or } \\
\quad \text { third trimester) }\end{array}$ & Cognitive test score & - & $\begin{array}{l}\text { Prenatal PAH exposure above the median }\left(17.96 \mathrm{ng} / \mathrm{m}^{3}\right) \text { was associated } \\
\text { with } 1.4 \text { points lower RCPM scores at } 5 \text { years of age }\end{array}$ \\
\hline $\begin{array}{l}\text { Perera et al., } \\
2009^{80}\end{array}$ & $\mathrm{PAH}$ & $\begin{array}{l}\text { Prenatal (3rd trimes- } \\
\text { ter) }\end{array}$ & Cognitive test score & - & $\begin{array}{l}\text { Prenatal PAH exposure above the median }\left(2.26 \mathrm{ng} / \mathrm{m}^{3}\right) \text { was associated with } \\
4.32 \text { points lower full-scale IQ and } 4.67 \text { points lower verbal IQ scores }\end{array}$ \\
\hline $\begin{array}{l}\text { Porta et al., } \\
2016^{81)}\end{array}$ & $\mathrm{NO}_{2}, \mathrm{PM}$ & Prenatal/postnatal & Cognitive test score & - & $\begin{array}{l}\text { A } 10 \mu \mathrm{g} / \mathrm{m} 3 \text { increase of } \mathrm{NO}_{2} \text { exposure during pregnancy was associated with } \\
1.4 \text { points lower verbal IQ and } 1.4 \text { points lower verbal comprehension IQ } \\
\text { scores at } 7 \text { years of age }\end{array}$ \\
\hline $\begin{array}{l}\text { Guxens et al., } \\
2014^{82)}\end{array}$ & $\mathrm{NO}_{2}, \mathrm{PM}$ & Prenatal & $\begin{array}{l}\text { Cognitive and psy- } \\
\text { chomotor develop- } \\
\text { ment test score }\end{array}$ & - & $\begin{array}{l}\text { A } 10 \mu \mathrm{g} / \mathrm{m}^{3} \text { increase of } \mathrm{NO}_{2} \text { exposure during pregnancy was associated with } \\
0.68 \text { points lower global psychomotor development score at 1-6 years of } \\
\text { age, but not with cognitive development }\end{array}$ \\
\hline Kim et al., 2014 ${ }^{83)}$ & $\mathrm{NO}_{2}, \mathrm{PM}_{10}$ & $\begin{array}{l}\text { Prenatal (entire preg- } \\
\text { nancy) }\end{array}$ & $\begin{array}{l}\text { Neurodevelopment } \\
\text { test score }\end{array}$ & - & $\begin{array}{l}\text { A } 10 \text { ppb increase of } \mathrm{NO}_{2} \text { exposure during pregnancy was associated with } \\
3.12 \text { points lower mental developmental index (MDI) and } 3.01 \text { points lower } \\
\text { psychomotor developmental index (PDI). A } 10 \mu \mathrm{g} / \mathrm{m}^{3} \text { increase of PM10 } \\
\text { exposure was associated with } 4.60 \text { points lower } \mathrm{MDI} \text { and } 7.24 \text { points } \\
\text { lower PDI at } 6 \text { months of age, but not at } 12 \text { or } 24 \text { months of age }\end{array}$ \\
\hline $\begin{array}{l}\text { Perera et al., } \\
2012^{79)}\end{array}$ & $\mathrm{PAH}$ & $\begin{array}{l}\text { Prenatal (3rd trimes- } \\
\text { ter) }\end{array}$ & Behavioral problem & - & $\begin{array}{l}\text { Prenatal PAH exposure above the median }\left(2.27 \mathrm{ng} / \mathrm{m}^{3}\right) \text { or maternal and cord } \\
\text { adducts (detectable or higher) was associated with symptoms of anxious/ } \\
\text { depressed and attention problems }\end{array}$ \\
\hline $\begin{array}{l}\text { Min and Min, } \\
2017^{86)}\end{array}$ & $\mathrm{NO}_{2}, \mathrm{PM}_{10}$ & Prenatal+postnatal & $\mathrm{ADHD}$ & - & $\begin{array}{l}\text { A } 1 \mu \mathrm{g} / \mathrm{m}^{3} \text { increase of } \mathrm{NO}_{2} \text { and } \mathrm{PM} 10 \text { exposure was associated with inci- } \\
\text { dence of childhood } \mathrm{ADHD} \text { ( } \mathrm{NO}_{2} \text { : } \mathrm{HR}, 1.03,95 \% \mathrm{Cl}, 1.02 \text { to } 1.04 ; \mathrm{PM} 10 \text { : } \mathrm{HR} \text {, } \\
1.18,95 \% \mathrm{Cl}, 1.15 \text { to } 1.21 \text { ) }\end{array}$ \\
\hline $\begin{array}{l}\text { Newman et al., } \\
2013^{84)}\end{array}$ & ECAT & Postnatal & ADHD symptoms & - & $\begin{array}{l}\text { Exposure to highest tertile of ECAT }\left(\geq 0.40 \mu \mathrm{g} / \mathrm{m}^{3}\right) \text { during child's first year of } \\
\text { life was associated with hyperactivity T-scores in the at risk range at } 7 \\
\text { years of age (OR, } 1.70 ; 95 \% \mathrm{Cl}, 1.15 \text { to } 1.21)\end{array}$ \\
\hline $\begin{array}{l}\text { Forns et al., } \\
2016^{85}\end{array}$ & $\mathrm{EC}, \mathrm{BC}_{1} \mathrm{NO}_{2}$ & Postnatal & ADHD symptoms & - & $\begin{array}{l}\text { Exposure to TRAPs exposure were not associated with ADHD symptoms } \\
\text { scores }\end{array}$ \\
\hline $\begin{array}{l}\text { Lam et al., } \\
\qquad 2016^{87)^{\prime}}\end{array}$ & $\mathrm{PM}_{10,} \mathrm{PM} 2.5$ & Prenatal+postnatal & ASD & 23 & $\begin{array}{l}\text { A } 10 \mu \mathrm{g} / \mathrm{m}^{3} \text { increase of } \mathrm{PM} 10 \text { and } \mathrm{PM} 2.5 \text { exposure was associated with ASD } \\
\text { (PM10: OR, } 1.07 ; 95 \% \mathrm{Cl}, 1.06 \text { to } 1.08 ; \mathrm{PM} 2.5: \text { OR, } 2.32 ; 95 \% \mathrm{Cl}, 2.15 \text { to } \\
\text { 2.51) }\end{array}$ \\
\hline $\begin{array}{l}\text { Flores-Pajot et al., } \\
2016^{88)}\end{array}$ & $\begin{array}{l}\mathrm{NO}_{2}, \mathrm{PM}_{10} \\
\mathrm{PM}_{2.5}, \mathrm{O}_{3}\end{array}$ & Prenatal/postnatal & ASD & 12 & $\begin{array}{l}\text { A } 10 \mathrm{ppb} \text { increase of } \mathrm{NO}_{2} \text { exposure during pregnancy was associated with } \\
\text { ASD (RR, } 1.05 ; 95 \% \mathrm{Cl}, 0.99 \text { to } 1.11) \text {. A } 10 \mu \mathrm{g} / \mathrm{m}^{3} \text { increase of } \mathrm{PM} 2.5 \text { expo- } \\
\text { sure during pregnancy was associated with } \mathrm{ASD} \text { (RR, } 1.34 ; 95 \% \mathrm{Cl}, 0.83 \\
\text { to } 2.17 \text { ) }\end{array}$ \\
\hline
\end{tabular}

$\mathrm{OR}$, odds ratio; $\mathrm{Cl}$, confidence interval; IQR, interquartile range.

a) No. of articles included in the meta-analyses (note that the number of articles can vary by air pollutants and outcomes).

autism spectrum disorder (ASD), and attention-deficit hyperactivity disorder (ADHD). A summary of individual studies and meta-analyses is provided in Table $3 .^{77-88)}$ There is growing evidence that exposure to air pollution, particularly TRAP, is related to cognitive and psychomotor development in children. 89,90) Several studies reported that pre- and postnatal exposure to polycyclic aromatic hydrocarbons $(\mathrm{PAHs}){ }^{77-80,91)} \mathrm{PM}_{2.5}$, and $\mathrm{NO}_{2}{ }^{81,82)}$ adversely affected cognitive development and behavior. Kim et al. ${ }^{83)}$ investigated the adverse effects of prenatal exposure to $\mathrm{PM}_{10}$ and $\mathrm{NO}_{2}$ on neurodevelopment over 24 months in Korean children. They found significant associations between $\mathrm{PM}_{10}$ and both cognitive and psychomotor development. Prenatal exposure to $\mathrm{NO}_{2}$ also adversely affected psychomotor but not cognitive development.

It is also noteworthy to highlight the association between air pollution and neurodevelopment disorders. A recent metaanalysis reported positive associations between prenatal exposures to $\mathrm{PM}_{10}, \mathrm{PM}_{2.5}, \mathrm{NO}_{2}$, and $\mathrm{O}_{3}$ with ASD. Postnatal exposure to $\mathrm{PM}_{2.5}$ and $\mathrm{NO}_{2}$ was associated with ASD. Relatively few studies investigated the associations between air pollution and ADHD; thus, those results are not yet conclusive. Newman et al. ${ }^{84)}$ found that exposure to elemental carbon attributed to traffic during the first year of life was related to higher scores of
ADHD-related symptoms in children. Meanwhile, Forns et al. ${ }^{85)}$ examined the associations between exposure to TRAP, including elemental carbon, black carbon, and $\mathrm{NO}_{2}$, at school and ADHD-DSM-IV scores and found no significant associations with ADHD symptoms. In Korea, Min and $\mathrm{Min}^{86}$ reported a significant association between exposure to $\mathrm{PM}_{10}$ and $\mathrm{NO}_{2}$ with childhood ADHD incidence, but further studies of different populations, the time window of exposure, and confounding are needed.

Overall, there is relatively consistent evidence of the associations between ambient air pollution and neurodevelopmental effects. However, there is a need to clarify the critical window of exposure in the pre- and postnatal periods. Moreover, further research must compare studies using different exposure/ outcome measurements and investigate the effects of sex, age, and environmental and social conditions.

\section{Discussion}

Most studies investigating the health effects of ambient air pollution in children estimated the associations between individual air pollutants and specific health outcomes. One of the 
common limitations of these studies is that it is difficult to assess the effects of exposure to multiple pollutants simultaneously. In the real world, the population is exposed to a mixture of pollutants in the atmosphere, so the health effects of air pollution may have been caused by a combination of those various pollutants. However, as air pollutants are correlated and interact with each other, it remains a challenge to disentangle the independent effects of individual pollutants or comprehensively estimate the effects of mixed air pollution.

The mechanisms of the adverse health effects of air pollution on children are also complex and remain unclear. Nonetheless, the inflammatory response and oxidative stress are often sug. gested to play important roles. In a panel study of New York City schoolchildren, Patel et al. ${ }^{92)}$ reported that black carbo and $\mathrm{NO}_{2}$ were associated with $\mathrm{pH}$ and 8-isoprostane, exhaled biomarkers of airway inflammation and oxidative stress, respectively. Toxicological studies have suggested that PM may stimulate the formation of reactive oxygen species (ROS), and continuous ROS exposure can impair lung function through pulmonary inflammation. ${ }^{93)}$ It was recently suggested that epigenetic changes may be involved in mechanisms linking air pollution to health. Air toxicants may alter the methylation degree of candidate genes related to cardiovascular diseases, respiratory diseases, and cancer. ${ }^{94,95)}$ These epigenetic modifications are expected to help identify the causal correlation between air pollution exposure and children's health.

Although the adverse effects of air pollution on health outcomes of children reviewed in this paper are generally well founded, different effect estimates or inconsistent results are often reported. There may be various reasons for heterogeneity between studies apart from analytical approaches, including study design and statistical methods. As mentioned before, air pollution is a mixture of various substances and individual air pollutants can interact with other air pollutants. The effects of individual pollutants can vary due to the different distribution of air pollutants between study areas. In particular, PM is a mixture of chemicals, unlike other gaseous pollutants. Since the toxicity of PM depends on chemical size and constituents, ${ }^{58,60,96,97)}$ differences in PM characteristics between regions can be a major cause of heterogeneity among studies.

In addition to the properties of air pollution, population vulnerability can explain interstudy heterogeneity. Several studies have shown that individual sociodemographic characteristics or the local environment could modify the association between ambient air pollution and health. ${ }^{38,62,66)}$ Among various factors, age is one of the most important effect modifiers in the pediatric population. A child is usually defined as a person below the age of 18 , but each study sets its own standard age. Even among populations under the age of 18, younger and older children may have different biological characteristics and outdoor activity patterns, resulting in inconsistent results between studies.

Accordingly, comparing existing studies requires an in-depth understanding of the characteristics of the study area and population. Related research has recently been underway in the
Asian region and developing countries beyond the US and Europe. When researchers aggregate studies conducted in various regions, it will be important to explore how various heterogeneity factors can affect the study results. These efforts will help us understand the complex causal correlation between air pollution and children's health, find gaps in existing research, and evolve to advanced research.

Epidemiological research on the health effects of air pollution provides scientific evidence for environmental health policy development. Environmental health policies should not only protect everyone's health from air pollution, they should reduce the health inequality caused by air pollution. In terms of health inequality, it is essential to consider social determinants of health in relation to air pollution ${ }^{98,99)}$ because they can affect the level of exposure to air pollution and the vulnerability to air pollution. A Korean study showed that socioeconomic status measured at the individual and regional levels was correlated with air quality index. ${ }^{100)}$ Low socioeconomic status can also make individuals more vulnerable to air pollution exposure by limiting healthy behaviors or health care utilization. Therefore, future research on air pollution and children's health should move toward considering various social contexts so that we can identify intervention points for reducing health inequality.

\section{Conclusions}

Review of the existing systematic reviews, meta-analyses, and recently updated studies revealed consistent evidence of the association between exposure to ambient air pollution and children's health, especially respiratory health and adverse birth outcomes, and growing evidence on neurodevelopmental outcomes. Studies conducted in Korea also provided a consistent conclusion, although the number of studies remains limited.

Despite these existing studies, the mechanism of adverse health effects of air pollution and the critical window of susceptibility remain unclear. There is also a need to identify causes of heterogeneity between studies in terms of measuring exposure/ outcome, study design, and differential characteristics of air pollutants and population.

\section{Conflicts of interest}

No potential conflict of interest relevant to this article was reported.

\section{References}

1. Hoek G, Krishnan RM, Beelen R, Peters A, Ostro B, Brunekreef B, et al. Long-term air pollution exposure and cardio- respiratory mortality: a review. Environ Health 2013;12:43.

2. Anderson HR, Atkinson RW, Bremner SA, Carrington J, Peacock J. Quantitative systematic review of short term associations between ambi- 
ent air pollution (particulate matter, ozone, nitrogen dioxide, sulphur dioxide and carbon monoxide), and mortality and morbidity. London: St George's University of London, 2007.

3. Brook RD, Rajagopalan S, Pope CA 3rd, Brook JR, Bhatnagar A, DiezRoux AV, et al. Particulate matter air pollution and cardiovascular disease: an update to the scientific statement from the American Heart Association. Circulation 2010;121:2331-78.

4. Brent RL, Weitzman M. The vulnerability, sensitivity, and resiliency of the developing embryo, infant, child, and adolescent to the effects of environmental chemicals, drugs, and physical agents as compared to the adult: preface. Pediatrics 2004;113:933-4.

5. World Health Organization. Effects of air pollution on children's health and development: a review of the evidence. Copenhagen: WHO Regional Office for Europe, 2005.

6. Schwartz J. Air pollution and children's health. Pediatrics 2004;113(4 Suppl):1037-43.

7. World Health Organization. Air pollution and child health: prescribing clean air. Geneva: World Health Organization, 2018.

8. Ward DJ, Ayres JG. Particulate air pollution and panel studies in children: a systematic review. Occup Environ Med 2004;61:e13.

9. Anderson HR, Favarato G, Atkinson RW. Long-term exposure to air pollution and the incidence of asthma: meta-analysis of cohort studies. Air Qual Atmos Health 2013;6:47-56.

10. Anderson HR, Favarato G, Atkinson RW. Long-term exposure to outdoor air pollution and the prevalence of asthma: meta-analysis of multicommunity prevalence studies. Air Qual Atmos Health 2013;6:57-68.

11. Fan J, Li S, Fan C, Bai Z, Yang K. The impact of PM2.5 on asthma emergency department visits: a systematic review and meta-analysis. Environ Sci Pollut Res Int 2016;23:843-50.

12. Lim H, Kwon HJ, Lim JA, Choi JH, Ha M, Hwang SS, et al. Short-term effect of fine particulate matter on children's hospital admissions and emergency department visits for asthma: a systematic review and metaanalysis. J Prev Med Public Health 2016;49:205-19.

13. Orellano P, Quaranta N, Reynoso J, Balbi B, Vasquez J. Effect of outdoor air pollution on asthma exacerbations in children and adults: systematic review and multilevel meta-analysis. PLoS One 2017;12:e0174050.

14. Zhang S, Li G, Tian L, Guo Q, Pan X. Short-term exposure to air pollution and morbidity of COPD and asthma in East Asian area: a systematic review and meta-analysis. Environ Res 2016;148:15-23.

15. Mehta S, Shin H, Burnett R, North T, Cohen AJ. Ambient particulate air pollution and acute lower respiratory infections: a systematic review and implications for estimating the global burden of disease. Air Qual Atmos Health 2013;6:69-83.

16. Barone-Adesi F, Dent JE, Dajnak D, Beevers S, Anderson HR, Kelly FJ, et al. Long-term exposure to primary traffic pollutants and lung function in children: cross-sectional study and meta-analysis. PLoS One 2015; 10:e0142565.

17. Weinmayr G, Romeo E, De Sario M, Weiland SK, Forastiere F. Short-term effects of PM10 and NO2 on respiratory health among children with asthma or asthma-like symptoms: a systematic review and meta-analysis. Environ Health Perspect 2010;118:449-57.

18. Bowatte G, Lodge C, Lowe AJ, Erbas B, Perret J, Abramson MJ, et al. The influence of childhood traffic-related air pollution exposure on asthma, allergy and sensitization: a systematic review and a meta-analysis of birth cohort studies. Allergy 2015;70:245-56.

19. Gasana J, Dillikar D, Mendy A, Forno E, Ramos Vieira E. Motor vehicle air pollution and asthma in children: a meta-analysis. Environ Res 2012; 117:36-45.

20. Khreis H, Kelly C, Tate J, Parslow R, Lucas K, Nieuwenhuijsen M. Exposure to traffic-related air pollution and risk of development of childhood asthma: a systematic review and meta-analysis. Environ Int 2017;100:1-31.

21. Nhung NT, Amini H, Schindler C, Kutlar Joss M, Dien TM, ProbstHensch N, et al. Short-term association between ambient air pollution and pneumonia in children: a systematic review and meta-analysis of time-series and case-crossover studies. Environ Pollut 2017;230:1000-8.

22. Min JY, Min KB, Cho SI, Paek D. Lag effect of particulate air pollution on lung function in children. Pediatr Pulmonol 2008;43:476-80.

23. Kim JH, Lim DH, Kim JK, Jeong SJ, Son BK. Effects of particulate matter (PM10) on the pulmonary function of middle-school children. J Korean Med Sci 2005;20:42-5.

24. Yoo Y, Choung JT, Yu J, Kim DK, Koh YY. Acute effects of Asian dust events on respiratory symptoms and peak expiratory flow in children with mild asthma. J Korean Med Sci 2008;23:66-71.

25. Kim BJ, Kwon JW, Seo JH, Kim HB, Lee SY, Park KS, et al. Association of ozone exposure with asthma, allergic rhinitis, and allergic sensitization. Ann Allergy Asthma Immunol 2011;107:214-9.

26. Yi SJ, Shon C, Min KD, Kim HC, Leem JH, Kwon HJ, et al. Association between exposure to traffic-related air pollution and prevalence of allergic diseases in children, Seoul, Korea. Biomed Res Int 2017;2017:4216107.

27. Lee JT, Kim H, Song H, Hong YC, Cho YS, Shin SY, et al. Air pollution and asthma among children in Seoul, Korea. Epidemiology 2002;13:4814.

28. Lee JT, Son JY, Kim H, Kim SY. Effect of air pollution on asthma-related hospital admissions for children by socioeconomic status associated with area of residence. Arch Environ Occup Health 2006;61:123-30.

29. Son JY, Kim H, Lee JT, Kim SY. Relationship between the exposure to ozone in Seoul and the childhood asthma-related hospital admissions according to the socioeconomic status. J Prev Med Public Health 2006; 39:81-6.

30. Lee JT. Associations between air pollution and asthma-related hospital admissions in children in Seoul, Korea: a case-crossover study. Korean J Prev Med 2003;36:47-53.

31. Lee JT, Cho YS, Son JY. Relationship between ambient ozone concentrations and daily hospital admissions for childhood asthma/atopic dermatitis in two cities of Korea during 2004-2005. Int J Environ Health Res 2010;20:1-11.

32. Park M, Luo S, Kwon J, Stock TH, Delclos G, Kim H, et al. Effects of air pollution on asthma hospitalization rates in different age groups in metropolitan cities of Korea. Air Qual Atmos Health 2013;6:10.1007/ s11869-013-0195-x.

33. Horne BD, Joy EA, Hofmann MG, Gesteland PH, Cannon JB, Lefler JS, et al. Short-term elevation of fine particulate matter air pollution and acute lower respiratory infection. Am J Respir Crit Care Med 2018;198:75966.

34. Nhung NTT, Schindler C, Dien TM, Probst-Hensch N, Perez L, Künzli N. Acute effects of ambient air pollution on lower respiratory infections in Hanoi children: an eight-year time series study. Environ Int 2018;110:139-48.

35. Romieu I, Lugo MC, Velasco SR, Sanchez S, Meneses F, Hernandez M. Air pollution and school absenteeism among children in Mexico City. Am JEpidemiol 1992;136:1524-31.

36. Park H, Lee B, Ha EH, Lee JT, Kim H, Hong YC. Association of air pollution with school absenteeism due to illness. Arch Pediatr Adolesc Med 2002;156:1235-9.

37. Gilliland FD, Berhane K, RappaportEB, Thomas DC, AvolE, Gauderman WJ, et al. The effects of ambient air pollution on school absenteeism due to respiratory illnesses. Epidemiology 2001;12:43-54.

38. Bai L, Su X, Zhao D, Zhang Y, Cheng Q, Zhang H, et al. Exposure to traffic-related air pollution and acute bronchitis in children: season and age as modifiers. J Epidemiol Community Health 2018;72:426-33.

39. Song J, Lu M, Zheng L, Liu Y, Xu P, Li Y, et al. Acute effects of ambient air pollution on outpatient children with respiratory diseases in Shijiazhuang, China. BMC Pulm Med 2018;18:150.

40. Wilcox AJ. On the importance: and the unimportance: of birthweight. Int JEpidemiol 2001;30:1233-41.

41. Osmond C, Barker DJ. Fetal, infant, and childhood growth are predictors of coronary heart disease, diabetes, and hypertension in adult men and women. Environ Health Perspect 2000;108 Suppl 3(Suppl 3):545-53.

42. Barker DJ. The fetal and infant origins of disease. Eur J Clin Invest 1995; 25:457-63.

43. Guo LQ, Chen Y, Mi BB, Dang SN, Zhao DD, Liu R, et al. Ambient air pollution and adverse birth outcomes: a systematic review and metaanalysis. J Zhejiang Univ Sci B 2019;20:238-52. 
44. Li X, Huang S, Jiao A, Yang X, Yun J, Wang Y, et al. Association between ambient fine particulate matter and preterm birth or term low birth weight: an updated systematic review and meta-analysis. Environ Pollut 2017;227:596-605.

45. Siddika N, Balogun HA, Amegah AK, Jaakkola JJ. Prenatal ambient air pollution exposure and the risk of stillbirth: systematic review and metaanalysis of the empirical evidence. Occup Environ Med 2016;73:573-81.

46. Lamichhane DK, Leem JH, Lee JY, Kim HC. A meta-analysis of exposure to particulate matter and adverse birth outcomes. Environ Health Toxicol 2015;30:e2015011.

47. Sun X, Luo X, Zhao C, Chung Ng RW, Lim CE, Zhang B, et al. The association between fine particulate matter exposure during pregnancy and preterm birth: a meta-analysis. BMC Pregnancy Childbirth 2015; 15:300.

48. Zhu X, Liu Y, Chen Y, Yao C, Che Z, Cao J. Erratum to: Maternal exposure to fine particulate matter (PM2.5) and pregnancy outcomes: a meta-analysis. Environ Sci Pollut Res Int 2015;22:3397-9.

49. Sapkota A, Chelikowsky AP, Nachman KE, Cohen AJ, Ritz B. Exposure to particulate matter and adverse birth outcomes: a comprehensive review and meta-analysis. Air Qual Atmos Health 2012;5:369-81.

50. Stieb DM, Chen L, Eshoul M, Judek S. Ambient air pollution, birth weight and preterm birth: a systematic review and meta-analysis. Environ Res 2012;117:100-11.

51. Lee BE, Ha EH, Park HS, Kim YJ, Hong YC, Kim H, et al. Exposure to air pollution during different gestational phases contributes to risks of low birth weight. Hum Reprod 2003;18:638-43.

52. Ha EH, Hong YC, Lee BE, Woo BH, Schwartz J, Christiani DC. Is air pollution a risk factor for low birth weight in Seoul? Epidemiology 2001; 12:643-8.

53. Cho YS, Son JY, Lee JT. Air Pollution Exposure and low birth weight of firstborn fetus: a birth cohort study in Seoul, 1999-2003. Korean J Environ Health Sci 2007;33:227-34.

54. Suh YJ, Kim H, Seo JH, Park H, Kim YJ, Hong YC, et al. Different effects of PM10 exposure on preterm birth by gestational period estimated from time-dependent survival analyses. Int Arch Occup Environ Health 2009;82:613-21.

55. Leem JH, Kaplan BM, Shim YK, Pohl HR, Gotway CA, Bullard SM, et al. Exposures to air pollutants during pregnancy and preterm delivery. Environ Health Perspect 2006; 114:905-10.

56. Kim OJ, Ha EH, Kim BM, Seo JH, Park HS, Jung WJ, et al. PM10 and pregnancy outcomes: a hospital-based cohort study of pregnant women in Seoul. J Occup Environ Med 2007;49:1394-402.

57. Ebisu K, Bell ML. Airborne PM2.5 chemical components and low birth weight in the northeastern and mid-Atlantic regions of the United States. Environ Health Perspect 2012;120:1746-52.

58. Ebisu K, Malig B, Hasheminassab S, Sioutas C, Basu R. Cause-specific stillbirth and exposure to chemical constituents and sources of fine particulate matter. Environ Res 2018;160:358-64.

59. Laurent O, Hu J, Li L, Kleeman MJ, Bartell SM, Cockburn M, et al. A statewide nested case-control study of preterm birth and air pollution by source and composition: California, 2001-2008. Environ Health Perspect 2016;124:1479-86

60. Sun X, Luo X, Zhao C, Zhang B, Tao J, Yang Z, et al. The associations between birth weight and exposure to fine particulate matter (PM2.5) and its chemical constituents during pregnancy: a meta-analysis. Environ Pollut 2016;211:38-47.

61. Ghosh R, Rankin J, Pless-Mulloli T, Glinianaia S. Does the effect of air pollution on pregnancy outcomes differ by gender?: a systematic review. En viron Res 2007;105:400-8.

62. Heo S, Fong KC, Bell ML. Risk of particulate matter on birth outcomes in relation to maternal socio-economic factors: a systematic review. Environ Res Lett 2019;14:123004.

63. Shmool JL, Bobb JF, Ito K, Elston B, Savitz DA, Ross Z, et al. Area-level socioeconomic deprivation, nitrogen dioxide exposure, and term birth weight in New York city. Environ Res 2015;142:624-32.

64. Erickson AC, Ostry A, Chan LH, Arbour L. The reduction of birth weight by fine particulate matter and its modification by maternal and neighbourhood-level factors: a multilevel analysis in British Columbia, Canada. Environ Health 2016;15:51.

65. Asta F, Michelozzi P, Cesaroni G, De Sario M, Badaloni C, Davoli M, et al. The modifying role of socioeconomic position and greenness on the short-term effect of heat and air pollution on preterm births in Rome, 2001-2013. Int J Environ Res Public Health 2019;16:2497.

66. Yi O, Kim H, Ha E. Does area level socioeconomic status modify the effects of PM(10) on preterm delivery? Environ Res 2010;110:55-61.

67. Ha EH, Lee BE, Park HS, Kim YS, Kim H, Kim YJ, et al. Prenatal exposure to PM10 and preterm birth between 1998 and 2000 in Seoul, Korea. J Prev Med Public Health 2004;37:300-5.

68. Lin CC, Santolaya-Forgas J. Current concepts of fetal growth restriction: part I. Causes, classification, and pathophysiology. Obstet Gynecol 1998; 92:1044-55.

69. Lee PC, Roberts JM, Catov JM, Talbott EO, Ritz B. First trimester exposure to ambient air pollution, pregnancy complications and adverse birth outcomes in Allegheny County, PA. Matern Child Health J 2013; 17:545-55.

70. Mohorovic L. First two months of pregnancy: critical time for preterm delivery and low birthweight caused by adverse effects of coal combustion toxics. Early Hum Dev 2004;80:115-23.

71. Tong S, Colditz P. Air pollution and sudden infant death syndrome: a literature review. Paediatr Perinat Epidemiol 2004;18:327-35.

72. Proietti E, Röösli M, Frey U, Latzin P. Air pollution during pregnancy and neonatal outcome: a review. J Aerosol Med Pulm Drug Deliv 2013;26:923.

73. Glinianaia SV, Rankin J, Bell R, Pless-Mulloli T, Howel D. Does particulate air pollution contribute to infant death?: a systematic review. Environ Health Perspect 2004;112:1365-71.

74. Ha EH, Lee JT, Kim H, Hong YC, Lee BE, Park HS, et al. Infant susceptibility of mortality to air pollution in Seoul, South Korea. Pediatrics 2003;111:284-90.

75. Hwang MJ, Cheong HK, Kim JH. Ambient air pollution and sudden infant death syndrome in Korea: a time-stratified case-crossover study. Int J Environ Res Public Health 2019;16:3273.

76. Son JY, Bell ML, Lee JT. Survival analysis of long-term exposure to different sizes of airborne particulate matter and risk of infant mortality using a birth cohort in Seoul, Korea. Environ Health Perspect 2011;119: 725-30.

77. Lovasi GS, Eldred-Skemp N, Quinn JW, Chang HW, Rauh VA, Rundle A, et al. Neighborhood social context and individual polycyclic aromatic hydrocarbon exposures associated with child cognitive test scores. J Child Fam Stud 2014;23:785-99.

78. Edwards SC, Jedrychowski W, Butscher M, Camann D, Kieltyka A, Mroz E, et al. Prenatal exposure to airborne polycyclic aromatic hydrocarbons and children's intelligence at 5 years of age in a prospective cohort study in Poland. Environ Health Perspect 2010;118:1326-31.

79. Perera FP, Tang D, Wang S, Vishnevetsky J, Zhang B, Diaz D, et al. Prenatal polycyclic aromatic hydrocarbon (PAH) exposure and child behavior at age 6-7 years. Environ Health Perspect 2012;120:921-6.

80. Perera FP, Li Z, Whyatt R, Hoepner L, Wang S, Camann D, et al. Prenatal airborne polycyclic aromatic hydrocarbon exposure and child IQ at age 5 years. Pediatrics 2009; 124:e195-202.

81. Porta D, Narduzzi S, Badaloni C, Bucci S, Cesaroni G, Colelli V, et al. Air pollution and cognitive development at age 7 in a prospective Italian birth cohort. Epidemiology 2016;27:228-36.

82. Guxens M, Garcia-Esteban R, Giorgis-Allemand L, Forns J, Badaloni C, Ballester F, et al. Air pollution during pregnancy and childhood cognitive and psychomotor development: six European birth cohorts. Epidemiology 2014;25:636-47.

83. Kim E, Park H, Hong YC, Ha M, Kim Y, Kim BN, et al. Prenatal exposure to PM1 and NO2 and children's neurodevelopment from birth to 24 months of age: Mothers and Children's Environmental Health (MOCEH) study. Sci Total Environ 2014;481:439-45.

84. Newman NC, Ryan P, Lemasters G, Levin L, Bernstein D, Hershey GK, et al. Traffic-related air pollution exposure in the first year of life and behavioral scores at 7 years of age. Environ Health Perspect 2013;121: 
731-6.

85. Forns J, Dadvand P, Foraster M, Alvarez-Pedrerol M, Rivas I, LópezVicente M, et al. Traffic-related air pollution, noise at school, and behavioral problems in barcelona schoolchildren: a cross-sectional study. Environ Health Perspect 2016;124:529-35.

86. Min JY, Min KB. Exposure to ambient PM10 and NO2 and the incidence of attention-deficit hyperactivity disorder in childhood. Environ Int 2017;99:221-7.

87. Lam J, Sutton P, Kalkbrenner A, Windham G, Halladay A, Koustas E, et al. A systematic review and meta-analysis of multiple airborne pollutants and autism spectrum disorder. PLoS One 2016;11:e0161851.

88. Flores-Pajot MC, Ofner M, Do MT, Lavigne E, Villeneuve PJ. Childhood autism spectrum disorders and exposure to nitrogen dioxide, and particulate matter air pollution: a review and meta-analysis. Environ Res 2016; 151:763-76.

89. Clifford A, Lang L, Chen R, Anstey KJ, Seaton A. Exposure to air pollution and cognitive functioning across the life course: a systematic literature review. Environ Res 2016;147:383-98.

90. Xu X, Ha SU, Basnet R. A review of epidemiological research on adverse neurological effects of exposure to ambient air pollution. Front Public Health 2016;4:157.

91. Perera FP, Rauh V, Whyatt RM, Tsai WY, Tang D, Diaz D, et al. Effect of prenatal exposure to airborne polycyclic aromatic hydrocarbons on neurodevelopment in the first 3 years of life among inner-city children. Environ Health Perspect 2006;114:1287-92.

92. Patel MM, Chillrud SN, Deepti KC, Ross JM, Kinney PL. Traffic-related air pollutants and exhaled markers of airway inflammation and oxidative stress in New York city adolescents. Environ Res 2013;121:71-8.
93. de Kok TM, Driece HA, Hogervorst JG, Briedé JJ. Toxicological assessment of ambient and traffic-related particulate matter: a review of recent studies. Mutat Res 2006;613:103-22.

94. Esposito S, Tenconi R, Lelii M, Preti V, Nazzari E, Consolo S, et al. Possible molecular mechanisms linking air pollution and asthma in children. BMC Pulm Med 2014;14:31.

95. Breton CV, Marutani AN. Air pollution and epigenetics: recent findings. Curr Environ Health Rep 2014;1:35-45.

96. Gehring U, Beelen R, Eeftens M, Hoek G, de Hoogh K, de Jongste JC, et al. Particulate matter composition and respiratory health: the PIAMA Birth Cohort study. Epidemiology 2015;26:300-9.

97. Prieto-Parra L, Yohannessen K, Brea C, Vidal D, Ubilla CA, Ruiz-Rudolph P. Air pollution, PM2.5 composition, source factors, and respiratory symptoms in asthmatic and nonasthmatic children in Santiago, Chile. Environ Int 2017;101:190-200.

98. O’Neill MS, Jerrett M, Kawachi I, Levy JI, Cohen AJ, Gouveia N, et al. Health, wealth, and air pollution: advancing theory and methods. Environ Health Perspect 2003;111:1861-70.

99. Schulz A, Northridge ME. Social determinants of health: implications for environmental health promotion. Health Educ Behav 2004;31:455-71.

100. Choi G, Heo S, Lee JT. Assessment of environmental injustice in Korea using synthetic air quality index and multiple indicators of socioeconomic status: a cross-sectional study. J Air Waste Manag Assoc 2016;66:28-37.

How to cite this article: Lee JT. Review of epidemiological studies on air pollution and health effects in children. Clin Exp Pediatr 2021;64:3-11. https://doi.org/10.3345/cep.2019.00843 